In $\begin{aligned} & \text { InMedia } \\ & \text { The French Journal of Media Studies }\end{aligned}$

8.2. $\mid 2020$

What do Pictures Do? (In)visibilizing the Subaltern

I Spy with my Little Eye... Queer(ing) CounterSurveillance Tactics of Camouflage and Opacity in Dean Sameshima's In Between Days (Without You) (1998)

\title{
Oliver Klaassen
}

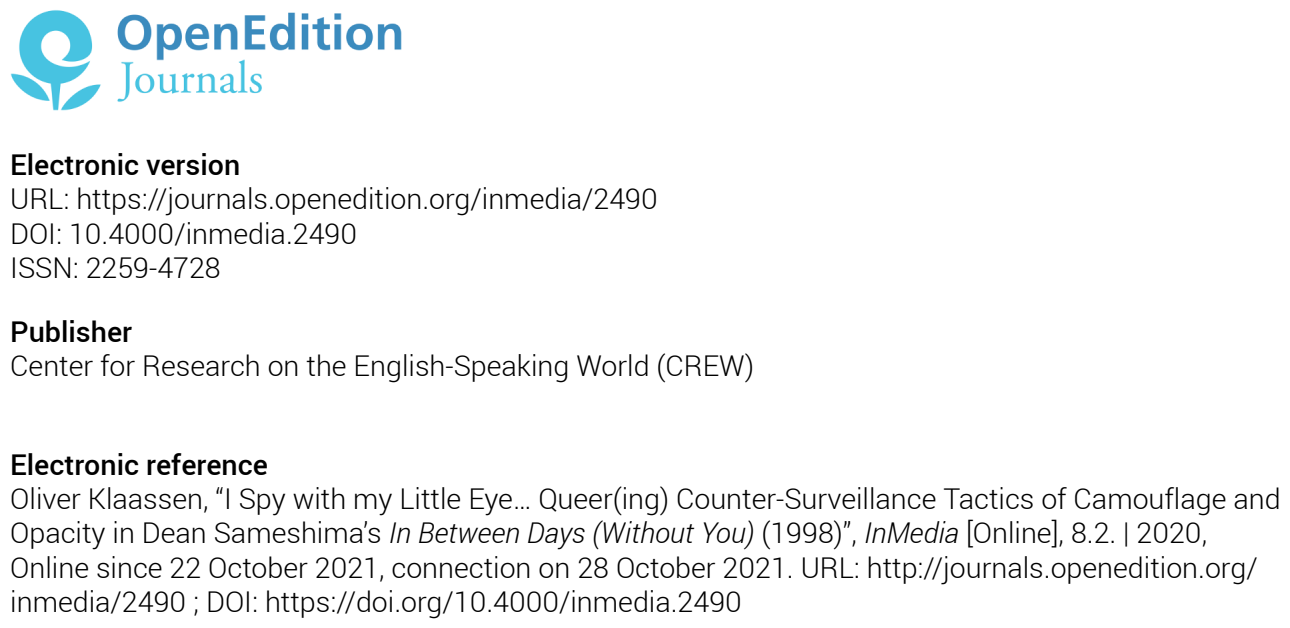

This text was automatically generated on 28 October 2021.

(c) InMedia 


\title{
I Spy with my Little Eye... Queer(ing) Counter-Surveillance Tactics of Camouflage and Opacity in Dean Sameshima's In Between Days (Without You) (1998)
}

\author{
Oliver Klaassen
}

\section{AUTHOR'S NOTE}

This article contains excerpts from a chapter on Dean Sameshima's In Between Days (Without You) (1998) from my doctoral thesis, provisionally titled, Aesthetic Ambiguity and Queer Engagement: Art Photography by Kaucyila Brooke, Dean Sameshima, David Benjamin Sherry, and Wolfgang Tillmans.

In the sense of a queer-feminist motivated (written) language I use the asterisk $\left(^{*}\right)$ to signal the denaturalization and cultural constructedness of categories such as man* and woman* (and the related pronouns he*/his* and she*/her*). It should make clear that the terms man* or woman*, for example, refer here to all persons who define themselves, are defined by, and/or see themselves made visible under this term. In addition, by making use of the gender gap (_), I want to mark the diversity of genderbased ways of existing. According to Steffen K. Hermann, at a linguistic level the underscore interrupts unquestioned representations and reproductions of the twogender system and instead gives trans* and inter* subject positions an intelligible space between masculine and feminine suffixes. Steffen K. Hermann, "Performing the Gap - Queere Gestalten und geschlechtliche Aneignung, “ arranca! 28, 2003. https:// arranca.org/archive?path=\%2Fausgabe\%2F28\%2Fperforming-the-gap <accessed on January 24, 2021>. 
By publishing this article and therefore inevitably shifting something that was supposed to remain invisible and unrecognized into the visual sphere, I am aware that someone could accuse me of disregarding the artist's claimed right to camouflage and opacity. Even though I have to admit that the accompanying ethical dilemma I am confronted with as a queer art studies researcher remains to some extent unresolved, I would like to emphasize that-out of a desire for protection on behalf of the artist and the depicted institutions-I would not have published my findings at the time of the creation of $I B D(W Y)$ in the 1990s, but also if the baths had still existed today and not least if I did not have the permission from the artist.

Even if today's zeitgeist keeps trying to convince us otherwise: Without the help of other fellow human beings, this article would not exist. First, I would like to thank the guest-editors for giving me the opportunity to publish this article and for their helpful comments. Second, thank you to members of two PhD Colloquiums, one at the Institute for Art and Visual Culture at Carl Ossietzky University Oldenburg and one at the Institute for Art Education at Justus Liebig University Giessen, for their feedback in earlier versions of this article. Third, thanks also to the anonymous reviewers for their constructive and valuable feedback, and to my colleague and friend Sophie Sexon for proofreading my article. And last but not least, my biggest thank you goes to Dean Sameshima (a) for creating important political art that sets my desire in motion in a special way, (b) for giving me exciting insights into the creation context and process for his photo series In Between Days (Without You) in long conversations and (c), together with Gavlak Gallery in Los Angeles and Palm Beach, for granting permission to reprint images of his* work.

\section{Introduction: Accessing Concealed Spaces}
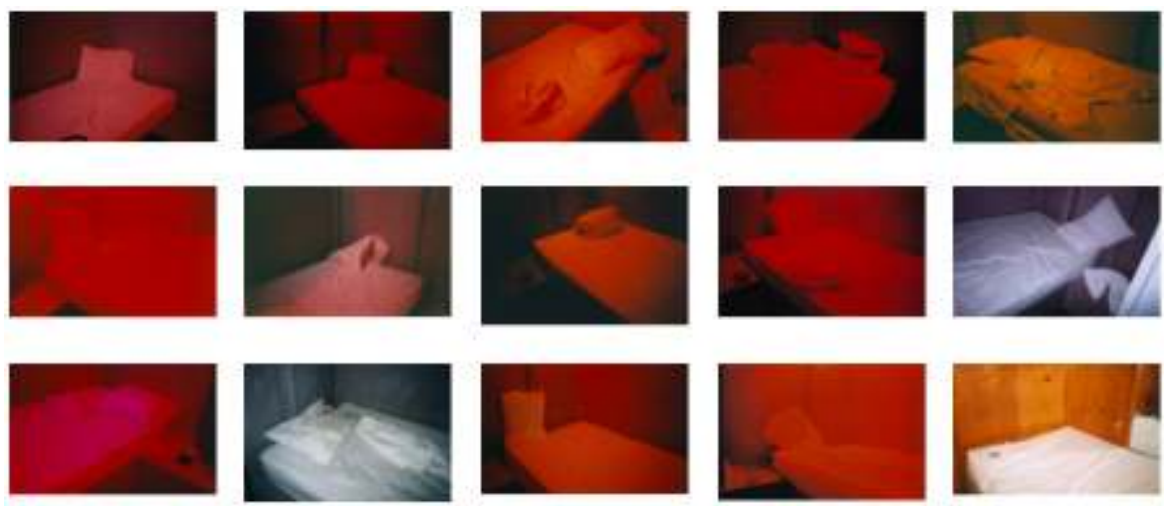

Figure 1: Dean Sameshima; In Between Days (Without You); 1998

15 c-type prints; image size: $88 / 9 \times 131 / 3 \mathrm{~cm} /$ paper size: $201 / 3 \times 252 / 5 \mathrm{~cm}$. (C) Courtesy of the artist and Gavlak Gallery, Los Angeles / Palm Beach.

1 The fifteen photographs in the series In Between Days (Without You) (in short: IBD(WY)) (1998) by Dean Sameshima ${ }^{1}$ share one common feature (Fig. 1): all the beds in the center of the rather minimalistic furnished rooms are deserted. ${ }^{2}$ The beds are the camera's focus and are illuminated by an artificial light source in mostly warm colors, but also stand out from the otherwise dark atmosphere with their white fabric covers. Despite the absence of human bodies, there are indicators that most of the beds were used before the photographs were taken, which is reflected in the crumpled and used 
pillows, sheets, and towels, among other things. The bed points to a particular form of private use and is thus charged with individual physicality.

2 Sameshima's art project consists of interior shots of no longer existing Los Angeles bathhouses (in short: baths) for men* who have sex with men* (MSM) shortly after the peak of the AIDS epidemic (1985-1995). ${ }^{3}$ Within gay culture, baths have a long history and tradition that can be traced back to the $18^{\text {th }}$ century. ${ }^{4}$ Specifically designed for community-building and cruising, ${ }^{5}$ similar to men*-only bars or darkrooms, ${ }^{6}$ for both the owners and the patrons of the MSM community, the term bathhouse was used as a legally protective measure to disguise its function from the outside world: primarily, as a meeting place for MSM. In times of repressive regimes, such as during and shortly after the peak phase of the AIDS epidemic in the United States, using this term was a strategic decision which enabled sex establishments for MSM to operate undetected. In this article, I choose to avoid the adjective gay in the context of baths, preferring to use the term bath or bathhouse, because within the LGBTIQ+ community it is historically a place that has attracted a male* audience looking, among other things, for sexual adventures with men*, including not-outed and heteroflexible men* who do not necessarily identify with labels like gay or bisexual.

The artist* ignored the no-photo policy in the baths, and therefore renders visible something that is normally not intended to be seen by the outside world. Nevertheless, a desire for invisibility and unrecognizability manifests itself in each of the photographs to the extent that the exact details of what happened before the shutter button of the camera was pressed remains outside designated, materially represented images. Even the title of the project is not able to provide any information about this insofar as the addition Without You seems to reproduce on a linguistic level what one already encounters when merely looking at the photographs: namely, that something is missing. The viewer's gaze is thus repeatedly directed to traces left behind, which act as functional omissions, so-called "blanks," giving rise to many questions such as: What do the traces of use refer to? Who has left them? What has just happened in the beds? Why is there an absence of human bodies? What added value does this relative invisibility hold in store?

\section{Queer(ing) Politics of In_Visibility: I Spy with my Little Eye...}

4 In the style of the popular children's game "I spy with my little eye..." I invite the readers of this article to explore the photo series $I B D(W Y)$ together with me, noting the tension between the visible and the invisible. This undertaking ties in with the transdisciplinary research perspective of studies on visual culture, which foregrounds the including and excluding mechanisms of images and questions the processes of making visible/invisible. ${ }^{8}$ With the notions of visibility and invisibility I refer to semantic nuances which are important to understand in context.

5 Visibility is often presumed to be intrinsic to presence and self-representation in the social space (e.g. being seen and heard). However, because visibility is the result of a constructive process that develops from existing norms and pictorial traditions, it is highly ambivalent and can therefore by no means be translated into social influence in a purely quantitative sense. ${ }^{9}$ For even if visibility is needed to initiate social change, it 
is linked to the judgment and stigmatization that arise from the gaze of one that is directed at the 'Other,' and that can be heteronormative, disciplining, and potentially violent..$^{10}$ This is why visibility allows-among other things-for surveillance and control by government agencies and secret services. Since IBD $(W Y)$ did not emerge in today's times of ubiquitous digital forms of surveillance (algorithms, networking apps, social media), "traditional forms"11 of surveillance such as measures of intersubjective, personal observation in the service of the police or police-like institution are meant. Although artistic works remain fundamentally caught up in being a mechanism of surveillance, I assume, following Andrea Mubi Brigheni, that they are parallelly capable of criticizing surveillance society. ${ }^{12}$

6 Conversely, invisibility refers both to minoritized people-often those deprived of the power of being seen and heard-and to 'normality,' invisibility making it possible to pass unseen as being the 'Other.' In the early 1990s Peggy Phelan refers-in reference to Michel Foucault and Jacques Lacan-to the threats and dangers of visibility for minoritized groups, which is why she* devotes her*self to the subversive possibilities of relative invisibility:

I am not suggesting that continued invisibility is the "proper" political agenda for the disenfranchised, but rather that the binary between the power of visibility and the impotency of invisibility is falsifying. There is real power in remaining unmarked; and there are serious limitations to visual representation as a political goal. Visibility is a trap [...]; it summons surveillance and the law; it provokes voyeurism, fetishism, the colonialist/imperial appetite for possession. ${ }^{13}$

7 Very much like Lee Edelman and Rosemary Hennessy, ${ }^{14}$ Phelan belongs to the theoreticians who have voiced their fears about the consequences of the most important demands of the early LGBTIQ+ movement: the demand for visibility, understood as the possibility of showing one's non-normative sexuality and gender in public and of gaining equal representation in the public sphere. Based on a skepticism towards, and criticism of, the politics and aesthetics of visibility in Western culture, Phelan deals with "the unmarked, unspoken, and unseen," ${ }^{15}$ which, in her* view, can be a characteristic of positions of power. Accordingly, the tactical added value of invisibility, of not being recognizable, of passing through, can lie in protection from the controlling gaze of heteronormative and other normative and normalizing instances.

\section{How to Navigate and Subvert Surveillance in a Particular Moment in Time?}

8 Since I am mainly interested in the risks of certain forms of becoming visible as well as the subversive potentials of invisibility, I want to concentrate primarily on the politics of visibility-a highly contested topic within queer theory and activism ${ }^{16}-$ in relation to the increased policing of intimacy and sexual practices in indoor cruising grounds. I use this framework, focusing on sites such as baths for MSM during and shortly after the peak of the AIDS-epidemic, to analyze how the artist Sameshima navigates and subverts surveillance in his* photographic art project $I B D(W Y)$, thereby succeeding in escaping hegemonic and/or normative forms of visibility. The interdisciplinary interlocking of art photography studies, (counter-)surveillance studies and queer studies, which I am aiming at in this article, has not yet been explored using $\operatorname{IBD}(W Y)$ as an example. The few existing analyses of $\operatorname{IBD}(W Y)$ are characterized by a range of the following thematic emphases: in addition to melancholy, mourning and loss-informed 
readings, ${ }^{17}$ and HIV/AIDS-informed readings, ${ }^{18}$ there are analyses in which the focus is either on cruising or (semi-)public sex ${ }^{19}$, on queer ecologies ${ }^{20}$ or on the relationship between ambiguity and queer engagement. ${ }^{21}$ In this context, previous research on $\operatorname{IBD}(W Y)$ either presents a psychoanalytic ${ }^{22}$ as well as a queer-ecological ${ }^{23}$ approach to visual culture studies or can be assigned to queer art history. ${ }^{24}$

Starting points for the analysis of the queer(ing) potentials of Sameshima's art are, on the one hand, those analyses with a focus on cruising or (semi-)public sex..$^{25}$ I would like to expand on those reflections with precise socio-historical contextual information, ${ }^{26}$ especially on the significance of baths for MSM during and shortly after the AIDS crisis, and explore the queer activism that developed from this epidemic in the 1990s. On the other hand, it is precisely because, in $\operatorname{IBD}(W Y)$, Sameshima navigates a line between revelation and concealment by consciously and simultaneously obscuring and revealing information that the position between visibility and invisibility interests me, and I would like to explore this in relation to the particular political stances of camouflage and opacity. My research interest in this in-between space, together with the constitutive relationship of dependence between visibility and invisibility (a guiding premise of representational critical approaches ${ }^{27}$ ), is reflected in the notation in_-visibility. ${ }^{28}$ With camouflage and opacity I refer to forms of protective concealments that can be defined as visual tactics designed to confuse the seeker and to prevent him_her from determining the one who wants to stay unrecognized. ${ }^{29}$ Camouflage and opacity, as tactics, are not something permanent but rather temporary, because, in the case of $I B D(W Y)$, they are employed by Sameshima in a historical context when they were most needed. Instead of claiming that camouflage and opacity are always and already queer, I rather propose that they may act as an inspiration for developing alternative models of queer(ing) (in__)visibility.

In exploring a queerness that invests and takes seriously refusals of certain forms of recognition and visibility, I am following more recent conceptualizations of queerness within art history, media studies, and visual studies. Especially since 2000 (shortly after Sameshima's $\operatorname{IBD}(W Y)$ was created), these fields have increasingly addressed the question of the extent to which artistic endeavors in art and visual culture can, through illegibility and unrecognizability, be resistant not only to xenophobia, surveillance, control and discrimination, but also to the commercial, capitalist and legal embrace of LGBTIQ+ culture in repressive as well as neoliberal, homonormative and homonational times. ${ }^{30}$ In using the mobile and ambiguous concept of queer, ${ }^{31}$ simultaneously as a research perspective and an object of analysis, my aim is to avoid a normative appropriation of queer(ing) and to maintain the provocative and challenging character of queer(ing) as an intellectual and epistemological project.

\section{Contested Private__Public Cruising Zones: The Private Rooms and Beds of Baths}

In the 1990s, Sameshima participated in L.A.'s vibrant cruising scene, documenting his* visits of cruising spots for MSM such as parks, public toilets (so-called tearooms), sex clubs and baths through photography in an autoethnographic manner. The artist was an integral part of this subcultural scene and therefore did not immerse him*self in a world that was 'foreign' to him* in order to take these photographs. In 1995 Saneshima published three interior photographs of tearooms in the last issue of the sex-positive 
magazine STEAM: A Quarterly Journal for Men, which disseminated information about public and semi-public sex for gay and bisexual men* ${ }^{32}$ In addition, the artist directs his* photographic gaze from the outside to the facades of various public restrooms located throughout Los Angeles in Tea Rooms (1995-97) taken in bright daylight. His* more comprehensive series Wonderland (1995-97) consists of photographs not only of the outer facades of sex clubs and baths, but also of other cruising spots for MSM in and around L.A. These include the military bunker in Palos Verdes, Griffith Park, Harbor City Park, and drawings on walls in tearooms again in bright daylight with no human bodies in sight.

For IBD $(W Y)$ in particular, the artist photographed rentable, so-called private rooms of baths with his* analogue Yashica T4 camera. Such rooms function as a private retreat in baths for MSM, ${ }^{33}$ allowing the customers to escape the hustle and bustle for a few hours when the door is closed-far from onlookers in rooms otherwise predominated by groups-and thus become functionally invisible. ${ }^{34}$ While the first fourteen photographs were shot in 1350 Club in Wilmington (1976-1984, 1986-2020), the last one is from Hollywood Spa (1974-2014) in Hollywood. All of the approximately 30 private rooms of $1350 \mathrm{Club}$ were located in the basement, some of which Sameshima photographed for his* art project. ${ }^{35}$ In conversation the artist told me that the small cells (about $5 \mathrm{~m}^{2}$ in size) were only equipped with the bare essentials, could be rented for a few hours, and were paid for in addition to the regular entrance fee. ${ }^{36}$ Apart from a single bed, which can be seen in all the photographs, each of the private rooms was furnished with a shelf next to the bed and a locker, as well as naked light bulb. Sameshima repeatedly photographed the used beds of the private rooms shortly before he* left those establishments. ${ }^{37}$ The exact details of what happened in the rooms is something that the artist leaves to the viewer's imagination, even though what is depicted (such as ashtrays with used cigarettes, condoms, a water bottle, wrinkled sheets and impressions in the beds) and the locations refer to past activities such as smoking, drinking, and sex.

The majority of unmade and used beds within IBD(WY) not only speaks historically to a long tradition of artistic depictions of beds, ${ }^{38}$ but also gives each photograph an affective, authenticating depth and thus conveys an immediacy and documentary character to the shots. But even though the bed, a sign of intimacy, ${ }^{39}$ seems predestined to represent the refuge of the private sphere, ${ }^{40}$ the bath's private room became a symbol of a tense controversy in the 1980s and 1990s, thus revealing the seeming contrast between public and private as an unsustainable construction. On the one hand, the city government and health authorities advocated surveilling or removing the small cells in order to counteract the spread of HIV/AIDS, and on the other hand, owners and clients advocated maintaining rentable rooms to guarantee the right of every client to privacy in commercial sex establishments. In particular, all doors to the private rooms of $1350 \mathrm{Club}$ were likely fitted with large holes to not only comply with the stricter health regulations during the peak of the AIDS epidemic but also to enable the surveillance of the activities taking place in the small cells. ${ }^{41}$ However, since all peepholes on the doors of the private rooms could be locked, in 19881350 Club was accused of not fully complying with this surveillance requirement to equip all private rooms with windows to prevent unprotected oral and anal sex. ${ }^{42}$ The former Club 1350 in Long Beach (1977-1986) was also forced to monitor all activities in their private rooms. Instead of complying with the regulation to remove not only all doors (thus depriving 
the visitors of their constitutional right to privacy) but also all beds from the rentable rooms, the owner Glen Moering voluntarily decided to close his* bath in Long Beach: "I think they're (perpetrating) a grave injustice [...]. If you were in your own home or in a hotel room, the city inspectors couldn't come in and ask you which side of the bed you were on. I can get AIDS anywhere; I will lose the club before I sacrifice the privacy of our members." ${ }^{43}$ The ban on individual cabins in baths was only one of the many tightened requirements for baths as a direct result of the AIDS epidemic. In addition to video surveillance and guardians who watched over risk-free sex, all rooms were brightly lit to make uninterrupted observation possible..$^{44}$ The latter does not seem to have been true at the time $I B D(W Y)$ was created, since in most of the photographs the viewer encounters lighting in warm colors (such as magenta, red, and orange) rather than strong brightness.

This policed and judicially contested status of the bed ${ }^{45}$ exposes the supposedly private as something permeated by mechanisms of state power, violence, and surveillance-an important insight to which Michel Foucault drew attention when he* remarked on the sexual dispositive. ${ }^{46}$ The increased surveillance of private rooms in baths, especially during and shortly after the peak of the AIDS epidemic, makes it clear that surveillance is not the opposite of privacy, but that they are ambivalent and intertwined concepts. ${ }^{47}$ In addition, this circumstance supports Lauren Berlant and Michael Warner's thesis that the great scandalous power of LGBTIQ+ movements is to bring discourses and phenomena historically assigned to the private sphere-most notably sex-into the public sphere, thus exposing hidden power structures ${ }^{48}$ At the same time, the forms of surveillance of indoor cruising grounds (such as baths) highlight the ambivalent and immanently sexualized character of surveillance. With Sameshima's focus on the bed as a semi-public space, he* refers to the instability and permeability of the categories of private and public in commercial sex establishments for MSM, without, however, being able or wanting to conceal the discursive power and effect that these categories have. In this undermining of binary oppositions (private vs. public) the queer(ing) potential of the photo series unfolds. Sameshima thus places him*self in the long tradition of feminist and queer critique, whose political struggle for political, economic, and social equality revolves centrally around the questioning and abolition of the dichotomy of privacy and the public sphere. ${ }^{49}$

\section{AIDS Epidemic and Increasing Surveillance of Baths}

Historically, cruising environments had to function invisibly in order to be permissible to the heteronormative outside world..$^{50}$ Like many other baths for MSM, $1350 \mathrm{Club}$ and Hollywood Spa operated as private membership clubs in order to render the business more or less invisible to the outside world and to keep their patrons safe. With regard to the outer facades of commercial cruising locations, such as baths, that Sameshima photographed for his* Wonderland series, there is usually no visible sign of what is happening inside ${ }^{51}$ For Jeffrey Walkowiak this camouflage characteristic fulfils the function of a linguistic shield:

[...] Sameshima emphasises the architectural mask these sex clubs wear in order to camouflage themselves in their immediate environment. This self-defensive act of camouflaging is vital to the existence of spaces that harbour such activities as queer sex. In the aftermath of the AIDS epidemic, sex clubs and other sites for anonymous sex in the USA came under close scrutiny by law authorities. Many of these 
establishments were forced to close their doors, some never to reopen. This camouflage effect, a nondescriptive architecture, allows these businesses to remain unseen and unknown to those who might endanger them, their patrons, and their communities. ${ }^{52}$

16 Very much the same could be said for the private rooms in baths for MSM. Although they indeed mimic a private bedroom in their furnishings in order to offer places of retreat for the customer, their 'banal' appearance, which the artist photographed for the series, can at the same time be used specifically to avoid police raids and surveillance. Without knowledge of the locations, which Sameshima suppresses in the title, the rooms are not necessarily recognizable to outsiders as private rooms in baths for MSM. As a result, the rooms, disguised as private bedrooms, deflect and mislead the controlling gaze of heteronormative and other normative and normalizing instances. The minimalist furnishings of the private rooms even play into Sameshima's hands here: precisely because they look so similar, one might also assume with a cursory glance that these were photographs of the same room taken over and over again. ${ }^{53}$

While Sameshima was working on $\operatorname{IBD}(W Y)$, conservative political trends and sexual panic fueled by the AIDS crisis had devastating consequences on many baths. These commercial cruising venues were falsely defamed as places of promiscuity and equated with a high risk of HIV infection and were therefore subject to increased police surveillance and control. ${ }^{54}$ Tattelman describes the increased visibility of baths that resulted from the AIDS crisis, and the dangers and risks involved, as follows:

The success of this "world of pleasure" may have resulted from the fact that the bathhouse was virtually invisible to those who did not support its practices. That situation began to change, however, with the discovery of HIV and the government's reaction to AIDS. The existence of bathhouses and press coverage of them made the bath mythic. HIV was transmitted through some of the sexual activities that took place in the bathhouse, and AIDS as a condition formed outside the bathhouse was used to interrupt the activities within the bathhouse. ${ }^{55}$

18 As a result, a lot of the baths for MSM in the US were being policed, raided, and were eventually shut down during the peak of the AIDS epidemic. ${ }^{56}$ In L.A., where Sameshima took his* photographs for IBD(WY), local authorities tried to relocate or permanently close baths by claiming, among other things, alleged violations of the city's building laws. In particular, a city ordinance enacted in 1986 banned all commercial sex establishments (such as brothels, sex cinemas, sex clubs, baths, and erotic massage parlors) from operating within 500 feet of residential areas, schools, and churches. This 'land-use issue' was perceived by both the owners and customers of baths for MSM, as well as gay activists, as a manifestation of homophobic resentment. Upon presentation of a binding lease agreement, the owners of baths in L.A. who were affected by the aforementioned city zoning law (and were therefore required to close) could apply for an extension until March 1991. 1350 Club, which was directly opposite a residential area and only 275 feet away from two schools, made successful use of this application for an extension. In 1993, another criminal case was prepared against the establishment and a closure was sought in court. ${ }^{57}$ Among other things, the testimony of an officer of the Los Angeles Police Department (LAPD), who was hired in advance to secretly investigate as a spy, was used against $1350 \mathrm{Club}$. This serves as yet another example of the constant covert police surveillance and control which the baths for MSM were under. ${ }^{58}$ Yet, despite massively discriminatory circumstances and several state-closure orders during and after the peak of the AIDS epidemic, 1350 Club lasted for over 40 years, closing in 2020 during the COVID-19-pandemic. Having fought many battles with 
the local authorities to keep the site open, in the last years of its existence, $1350 \mathrm{Club}$ also welcomed trans women on a monthly basis as part of the Temptation TUESDAY event series. The artist comments on the bath's closure on his* Instagram account as follows:

A very important Southern California institution for gay, bi, queer men has closed due to the pandemic. 1350 Wilmington was my favorite bathhouse. It was one of the few spaces I felt fully comfortable in because the clientele were mostly men of color, as was the staff. It was a safe space where men could play and socialize (like all bathhouses), as well as get tested anonymously for STIs and HIV and receive counseling. I believe it's been around since the 70s [...]. In 1997 I created a photographic series called Inbetween [sic] Days (Without You) inside 1350 and photographed the interior during my last visit in January. Can't believe it won't be there on my next visit to LA. [...]..$^{59}$

19 As "gay sexual institutions of the pre-AIDS 1970s and 1980s" 60 where "[g]ay male promiscuity happily emerged from centuries of repression," ${ }^{61}$ the baths, according to George Chauncey, created "an environment in which homosexual activity was encouraged and safeguarded" ${ }^{62}$ and still serve as inspiration for many artists today. ${ }^{63}$ Although it is not my intention to idealize baths as places of queer utopia, particularly because of their racist/phobic and exclusionary mechanisms, ${ }^{64}$ these semi-public spaces nevertheless allow a queering of what belonging means in terms of clear roles, processes, and boundaries, as well as establishing a certain spatial order in history and culture. ${ }^{65}$

\section{Invisibility, Camouflage, Opacity, and Counter- Surveillance}

As my brief historical excursus on the significance of the private rooms of $1350 \mathrm{Club}$ in Wilmington made clear, creating a photograph of two men* in a bath's private room during and shortly after the peak of the AIDS epidemic could have had devastating consequences not only for the artist, but also for the photographed persons and institutions. First, photographing explicit cruising acts would have been a violation not only of anonymity but also of the no-photo rules of the baths for MSM, probably resulting in a ban from the establishments for Sameshima. Second, it could have harmed the depicted persons, because revealing their non-normative sexual desires could have resulted in discriminatory and/or criminal prosecution. Third, by creating sexually explicit photographs, Sameshima would have played into the hands of the strongly prevailing surveillance measures of cruising places and the radical right-wing use of sexualized images for antigay propaganda, which was still prevalent at the time. Fourth, creating sexually explicit gay male* imagery would have had resulted in fueling the homophobic resentments already brought to gay men* and baths for MSM during the AIDS crisis: meaning the problematic association of AIDS with male homosexuality and the promiscuous, immoral (sexual) behavior attributed to gay men*, in particular. This would have resulted either in further surveillance and control measures or in the removal of private rooms; in the worst case, the closure of the baths. Lastly, an explicit artistic thematization of sexuality in the private rooms of baths involving homo-, biand/or heteroflexible men* would have also blocked Sameshima's access to the hegemonic art market in the 1990s. Against the background of these serious 'traps of 
visibility,' it is no surprise that the artist therefore decided to camouflage queer and/or AIDS related content in his* photographic work.

With $\operatorname{IBD}(W Y)$, Sameshima seems to be more interested in the illegible and nonrecognizable than in LGBTIQ+ politics that is concerned with creating a coherent presence and a visibility. Insofar as he* seems to have chosen invisibility in his* photographic art project, meaning the absence of human bodies, this seems to be rather a resistant act of refusal in the sense that it offered homo-, bi- and/or heteroflexible men* and their increasingly surveilled community-building and cruising spaces protection from homophobic attacks as well as surveillance, control and prosecution. In the opinion of Hanna Rose Shell it is this "not showing up," ${ }^{66}$ which she* identifies as the logic of camouflage, "a strategic necessity and a worthy aspiration." 67 As a practice of making oneself invisible, camouflage, generally understood as deception through concealment, was established by the military in the First World War when so-called reconnaissance planes were equipped with cameras, thereby producing a new relationship to visibility. ${ }^{68}$ Strategies of visual disorganization are always inseparable from the media of perception and surveillance to which they react. It is likely not photography that primarily comes to mind when reflecting on the concept of camouflage historically within the various fields of visual culture, especially because photography "has long been regarded for its power to make visible and to document the unseen and unknown aspect of our world." ${ }^{69}$ Shell refutes this assumption with her* focus on the interrelationships between technological advances in photography and film and developments in camouflage media and consciousness. ${ }^{70}$ Shell shows us that it is impossible to discuss modern developments in concealment and deception without concurrently studying camera technologies, vision and visuality, surveillance, film and reconnaissance. This is because photographic technologies were forced to adapt in line with camouflage's ongoing development, thus rendering the two developments somewhat inseparable.

In Sameshima's work on cruising, the absence of human bodies, which Andy Campbell describes as an act of "[d]epopulating the scene of sexual activity," feature that is similarly present in many photographic art projects depicting cruising locations in the $1990 \mathrm{~s},{ }^{72}$ but it also represents a repeated camouflaged queer(ing) strategy employed by artists during the institutionally homophobic and AIDS-phobic atmosphere of the 1980s and 1990s. Jonathan Katz, one of the curators of the exhibition Art AIDS America in which IBD(WY) was on display, calls this camouflaged queer art "poetic postmodernism"73 that heavily uses codes and symbols. Christian Lütjens and Paul Schulz pursued a similar line of argument two years before the first stop of Art AIDS America by describing Sameshima's series as programmatic for art that would react to the AIDS crisis more implicitly than explicitly. ${ }^{74}$ For them, characteristic of this aesthetic, which can be observed especially after 2000 , is the strategic use of ambiguity and "ciphering elements," 75 i.e. the use of symbols, signs and codes for AIDS, which "are often only recognizable at second glance." ${ }^{76}$ Two years earlier, Rock Hushka also argued similarly and dichotomously: locating the spectrum of artistic responses to a changing AIDS epidemic between "direct address to heavily camouflaged personal expression." 77

23 Furthermore, I interpret the combination of not showing human bodies on a visual level, and of covering up the shooting location on a linguistic level in the title as a radical attitude of refusal that stands up for a "right to opacity" in the sense of Édouard Glissant. ${ }^{78}$ Even though the philosopher and poet Glissant primarily argued for that 
'right' and an ethical form of relation to the 'Other' to criticize the dominant Western culture of transparency, ${ }^{79}$ it is not to be confused with an insistence on intransparency, i.e. obscurity. Instead, with opacity he* is more concerned with a sensitivity for the porous, vague, and flickering. ${ }^{80}$ With regard to the visual sphere, opacity offers a form of protest against acts that insist on rendering subjects readable, legible, and categorizable. The aforementioned "right to opacity" can thus very well be understood as an aesthetic attitude that unfolds between transparency and obscurity, and that latently tends towards a phenomenological attention that is interested in shades or strives to perceive intermediate tones and shades of gray that are otherwise overlooked. This in-betweenness, a state that allows for things not to be visible, is what activates opacity: which is also invoked in the title of Sameshima's series, yet might not completely conceal its object of protection. Nicholas De Villiers also holds this view:

Opaque and transparent-taken to their limits-don't work as opposites, since for something to be fully transparent it would be invisible, and for something to be completely opaque would mean a complete blockage of vision altogether, another invisibility. So opacity is visible only outside of the purity of the opposition opaque/ transparent itself. ${ }^{81}$

De Villiers conceptualizes opacity as an alternative queer strategy or tactic, a practice of queer living that resists confession, fixed identity categories, and public visibility as obligatory elements of LGBTIQ+ identity. ${ }^{82}$ For him* queer opacity is a "visual metaphor" that "tries to envision alternatives to commands to be 'visible' but also 'transparent' to a gaze that seeks a clear, responsible identity." ${ }^{83}$ In recent years, other queer theorists have proposed opacity as a generative and necessary frame for contemporary feminist and queer art politics. ${ }^{84}$ Most popular is the artist, filmmaker, and writer Zac Blas who-inspired by Glissant-pleas for a queerness that "is an illegibility or opacity, a refusal that remakes visibility and regimes of recognition outside of standardization through speculative and utopian experimentation and fantasy." 85

For Sameshima, opacity seems to be, above all, a form of resistance to surveillance. Even though $I B D(W Y)$ inevitably works towards surveillance and control by making the inside of private rooms in baths visible, what is depicted nevertheless resists the hegemonic-surveillant-gaze. By not showing human bodies and by suppressing information about the shooting location in the title, the series retains the safe space character and works against police surveillance and control of baths during and shortly after the peak of the AIDS epidemic, which is why-following Jessica Lingel-I understand the series as an "anti-surveillance counter-conduct." ${ }^{86}$ This form of queer art "insists that oppressive forms of surveillance are not all-encompassing, demonstrating aesthetic re-alignments against a surveillant gaze." ${ }^{\prime 7}$ Sameshima, following up on methods of tactical invisibility with $\operatorname{IBD}(W Y)$, thus operates at the level of managing and subverting rather than avoiding surveillance, thereby entering a level of engagement that articulates opacity as a tool of critique.

\section{Reclaiming Promiscuity and Queer(ing) as Possibility}

One major reason that queer activism emerged was as a response to the AIDS crisis of the 1980s which led to the following shifts: from sexual identities to (safer) sexual practices; from essential identities to identities based on affiliation; ${ }^{88}$ and towards resistance to the homophobic representation of AIDS as a 'gay disease' in science, 
policies, healthcare, and media representations, ${ }^{89}$ which had escalated homophobia and was costing those with AIDS their lives. This renewal of radical activism was the starting point for groups like ACT UP and Queer Nation. Sameshima published his* photo series at a time when there was more visible resistance to the practice of policing public sex, finding expression not only in protests but also in a variety of scholarly publications..$^{90}$ Commercial sex establishments for MSM were not only attacked by a repressive state power, but also by a reactionary, sex-negative LGBTIQ+ community. ${ }^{91}$ The public discussion about commercial cruising venues in the 1980 s and 1990 s therefore resulted in a division of the LGBTIQ+ community into two camps: conservative-normative and radical-activist. Baths are of central interest for queer activism. The bed seems to serve as a reminder of this, precisely because sex is an essential part of social structuring, sexual action and the fantasy spaces made possible by private rooms in baths. With his* photo series, and much like the activist group SexPanic!, ${ }^{92}$ Sameshima seems to reclaim-in the words of Douglas Crimp-"our subjectivities, our communities, our culture... and our promiscuous love of sex." ${ }^{93}$ Very much the same could be said for Sameshima's most recent series being alone which consists of largely 'depopulated' photographs taken with a smartphone in Berlin's porn cinemas, which the artist had started to post shortly before the COVID-19 pandemic on Instagram. In echoing the title of Crimp's seminal 1987 essay about AIDS "How to Have Promiscuity in an Epidemic?", Sameshima opposes the common (conservative and phobic) demands that are often made during times of crisis such as the AIDS epidemic and COVID-19 pandemic; namely that people should stop having sex, and the insistence that promiscuity allegedly kills.

In operating under cover of camouflage and opacity, the series empowers the marginalized-the clientele of the baths in particular-by giving them space for existence, expression, and safety. Even though all photographs are completely devoid of any human presence, they nevertheless point to the traces left behind and therefore to what has occurred there in the empty yet sexually charged atmosphere of private rooms in baths. The photos reflect the hardly visible and ephemeral character of the act of cruising itself, ${ }^{94}$ when bodies are in motion, restless against any semantic fixation and metaphorical restriction, searching for new encounters and connections that are always short-lived, fragmented, and fragile. The erotic potential of the photographs unfolds through strategic invisibility in that the absence of human bodies stimulates the viewer's imagination and desire (especially when becoming aware of the locations the photographs were taken in). Similar to the practice of cruising, the viewer is invited to the pleasurable "act of looking, wondering, and finding" ${ }^{95}$ rather than focusing on a defined finality. ${ }^{96}$ Therefore, Sameshima's photographed empty beds in the private rooms of baths seem to make room for the possibility of experiencing (new) sexual encounters, for-as formulated by José Esteban Muñoz-“queerness [is] a possibility, a sense of self-knowing, a mode of sociality and relationality," ${ }^{97}$ a circumstance that is also reinforced by the invocation Without You in the title.

\section{Queering the Visual Sphere: Conclusion and/or Learning from the Marginalized}

As I have shown, the bathhouses surveillance practices have been developed in a historical context marked by AIDS, homophobia and sex-negativity, but so, too, have 
tactics of opposition among the marginalized. Even though Sameshima took photographs of the private rooms of baths during a time of increasing conditions of continual surveillance, the artist found a way to play with the paradox of visibility by naming a set of practices that are available to those who recognize the impossibility of avoiding surveillance, and those who instead seek to subvert it. This turns camouflage and opacity into protective tools to convey the strength and resistant capabilities of baths for MSM under attack, thereby offering the potential of negotiating and queering the visual sphere. For gay artists of color like Sameshima, experiences of surveillance and monitoring are continual and potentially life-threatening, and this is why I am convinced that they have so much to teach us about (counter-)surveillance and the politics of in_visibility.

\section{BIBLIOGRAPHY}

Berlant, Lauren and Michael Warner, "Sex in der Öffentlichkeit," in Outside. Die Politik queerer Räume, edited by Matthais Hesse, Marc Siegel, and Michaela Wünsch, 77-104. Berlin: b_books 2005 [2000].

Bersani, Leo. "Is the Rectum a Grave?" October 43, (1987): 197-222.

Bérubé, Allan. “The History of Gay Bathhouses.” In Policing Public Sex: Queer Politics and the Future of AIDS Activism, edited by Dangerous Bedfellows, 187-220. Boston, MA: South End Press, 1999.

Betsky, Aaron. Queer Space: Architecture and Same Sex Desire. New York: William Morrow. 1997. Beynon, John. "Bathhouses and Sex Clubs." In Gay Histories and Cultures, edited by George E. Haggerty, 155-159. New York: Taylor \& Francis Inc., 2000.

Binson, Diane and William J. Woods, eds., Gay Bathhouses and Public Health Policy. New York: Routledge. 2003.

Blas, Zach ed. In Practice: Opacities. [Special Issue]. Camera Obscura. Feminism, Culture, and Media Studies 31, (2 92), September 2016.

Blechmann, Hardy and Alex Newman eds. DPM Disruptive Pattern Material. An Encyclopaedia of Camouflage: Nature, Military, Culture. London: DPM, 2004.

Bolton, Ralph, John Vincke, and Rudolf Mak. “Gay Baths Revisited: An Empirical Analysis.” GLQ: A Journal of Lesbian and Gay Studies 1, no. 3 (1994): 255-73.

Brighenti, Andrea Mubi. “Artveillance: At the Crossroads of Art and Surveillance." Surveillance \& Society 7, no. 2 (2010): 175-186.

Buitron, Michael. "From Laud Humphries to Dean Sameshima: An Ode to the Continuum of Desire (Part 1)." In Leap Into the Void (Blog), 10/07/2008. https://imoralist.blogspot.com/2008/10/fromlaud-humphries-to-dean-sameshima.html <accessed on May 15, 2021>

Campbell, Andy. Bound Together. Leather, Sex, Archives, and Contemporary Art. Manchester: Manchester University Press, 2020. 
---. Dean Sameshima: Public Sex Brochure for the Exhibition of the Same Name at the She Works Flexible Gallery in Houston, TX 05/05/2016-06/03/2016). 2016.

Chauncey, George. New York: Gender Gay, Urban Culture - and the Making of the Gay Male World, 1890-1940. New York: Basic Books, 1995.

Cheng, Jih-Fei. "Development is a Façade: Dean Sameshima's In Between Days (Without You) and the Queer Ecologies of Downtown Los Angeles." Lecture on March 11, 2017 in the context of the conference Viral Representation: On Aids and Art. A Conference (03/10/2017-03/11/2017) at Alphawood Gallery in Chicago. https://vimeo.com/210682462 <accessed on May 15, 2021> Crimp, Douglas. "How to Have Promiscuity in an Epidemic." October 43, (1987): 237-271. Dangerous Bedfellows ed. Policing Public Sex: Queer Politics and the Future of AIDS Activism. Boston, MA: South End Press, 1996.

Dannenberg, Nadine. "Queer Surveillance Studies. Überlegungen zu der Schnittstelle von Queer Theory und Surveillance Studies." GENDER 3, (2019): 26-40.

De Villiers, Nicholas. “Afterthoughts on Queer Opacity." InVisible Culture: An Electronic Journal of Visual Culture 22, (2015). https://ivc.lib.rochester.edu/afterthoughts-on-queer-opacity/ <accessed on January $24,2021>$

---. Opacity and the Closet: Queer Tactics in Foucault, Barthes, and Warhol. Minneapolis: University of Minnesota Press, 2014.

Edelman, Lee. Homographesis: Essays in Gay Literary and Cultural Theory. London and New York: Routledge, 1994.

Eler, Alicia. “The Faceless of Tomorrow Begins Today.” Hyperallergic (2013). https:// hyperallergic.com/73888/the-facelessness-of-tomorrow-begins-today/ <accessed on January 24, 2021>

Espinoza, Alex. CRUISING: An Intimate History of a Radical Pastime. Los Angeles: Unnamed Press, 2019.

Evans, Caroline and Lorraine Gamman. “The Gaze Revisited, or Reviewing Queer Viewing." In A Queer Romance: Lesbians, Gay Men and Popular Culture, edited by Paul Burston and Colin Richardson, 13-56. New York: Routledge, 1995.

Foucault, Michel. Der Wille zum Wissen. Sexualität und Wahrheit I. Frankfurt/Main: Suhrkamp, 1977. Getsy, David. “The Queer Theses on Abstraction.” In Queer Abstraction, edited by Jared Ledesma, 65-75. Des Moines: Des Moines Art Center, 2019.

Glissant, Éduouard. Philosophie de la Relation. Paris: Gallimard, 2009.

Kultur und Identität. Ansätze zu einer Poetik der Vielheit. Translated by B. Thill. Heidelberg: Wunderhorn, [1996] 2005.

---. Poétique de la Relation. Paris: Gallimard, 1990.

Haeberle, Erwin J. "Die Schließung der "Schwulenbäder" in San Francisco." In Sexualwissenschaft und Sexualpolitik. Spannungsverhältnisse in Europa, Amerika und Asien, edited by Rolf Gindorf and Erwin J. Haeberle, 187-194. Berlin and New York: Walter de Gryter, 1992.

Halberstam, Jack. The Queer Art of Failure. Durham: Duke University Press, 2011. 
Haldane, David. “Gay Bathhouse Under Pressure to Find Privacy for Sexual Acts.” Los Angeles Times, April 27, 1986. https://www.latimes.com/archives/la-xpm-1986-04-27-hl-23919-story.html $<$ accessed on October 13, 2019>

“Anti-AIDS Crusader Attacks Relocation of Gay Bathhouse.” Los Angeles Times, July 17, 1986. https://www.latimes.com/archives/la-xpm-1986-07-17-cb-21512-story.html <accessed on October 13, 2019>

Hall, Donald E., and Annamarie Jagose eds. The Routledge Queer Studies Reader. London; New York: Routledge, 2012.

Hall, Stuart ed. Representation: Cultural Representations and Signifying Practices. London: Sage Publications Ltd, 1997.

Hausen, Karin. "Öffentlichkeit und Privatheit. Gesellschaftspolitische Konstruktionen und die Geschichte der Geschlechterbeziehungen.” In Frauengeschichte - Geschlechtergeschichte, edited by Karin Hausen and Heide Wunder, 81-88. Frankfurt/Main, New York: Campus, 1992.

Hennessy, Rosemary. Profit and Pleasure: Sexual Identities in Late Capitalism. New York and London: Routledge, 2000.

Hermann, Steffen K. "Performing the Gap - Queere Gestalten und geschlechtliche Aneignung." arranca! 28, (2003). https://arranca.org/archive?path=\%2Fausgabe\%2F28\%2Fperforming-the-gap $<$ accessed on January 24, 2021>

Hushka, Rock. "Undetectable. The Presence of HIV in Contemporary American Art." In Art AIDS America, edited by Rock Hushka and Jonathan David Katz, 128-141. Seattle; London: University of Washington Press, 2015.

--_. "It's an Image of Sex. It's Not about AIDS. The Legacy of the AIDS Crisis on American Art (It's Never Not about HIV).” GIA Reader 22, no. 3 (2011). https://www.giarts.org/article/ it\%E2\%80\%99s-image-sex-it\%E2\%80\%99s-not-about-aids <accessed on June 12, 2020>

Husslein-Arco, Agnes. "Vorwort / Foreword." In Schlaflos - Das Bett in Geschichte und Gegenwartskunst / Sleepless - The Bed in History and Contemporary Art, edited by Agnes Husslein-Arco and Mario Codognato, 6-8. Wien: Belvedere, 2015.

-- - and Mario Codognato eds. Schlaflos - Das Bett in Geschichte und Gegenwartskunst / Sleepless The Bed in History and Contemporary Art. Wien: Belvedere, 2015.

Iser, Wolfgang. Der Implizite Leser: Kommunikationsformen des Romans von Bunyan bis Beckett. München: Wilhelm Fink Verlag, 1972.

Jagose, Annemarie. Queer Theory: An Introduction. New York: New York University Press, 1997.

Jung, Thomas and Stefan Müller-Dohm. "Kultur und Natur im Schlafraum." In

Kulturinszenierungen, edited by Klaus Neumann-Braun and Stefan Müller-Dohm, 239-261.

Frankfurt am Main: Suhrkamp Verlag, 1995.

Kafer, Gary and Daniel Grinberg. "Editorial: Queer Surveillance.” Surveillance \& Society 17, no. 5 (2019): 592-601.

Katz, Jonathan David. "How AIDS Changed American Art." In Art AIDS America, edited by Rock Hushka and Jonathan David Katz, 24-45. Seattle; London: University of Washington Press, 2015.

_-_ “John Cage's Queer Silence; or, how to Avoid Making Matters Worse.” GLQ 5, no. 2 (1999): 231-252 
-—- and David C. Ward, Hide/Seek: Difference and Desire in American Portraiture. Washington, DC.: Smithsonian Institution, 2010.

Kemp, Wolfgang ed. Der Betrachter ist im Bild: Kunstwissenschaft und Rezeptionsästhetik. Berlin: Dietrich Reimer Verlag, 1992.

Khan, Ali. “The Invasion of Sexual Privacy.” San Diego Law Review 23, (1986): 957-977.

Klaassen, Oliver. "Fotografische Ambiguität \& getarnte Queerness: Der Versuch einer exemplarischen Verhältnisbestimmung." In Mehrdeutigkeit gestalten: Ambiguität und die Bildung demokratischer Haltungen in Kunst und Pädagogik, edited by Ansgar Schnurr, Sabine Dengel, Julia Hagenberg, and Linda Kelch, 253-271. Bielefeld: Transcript, 2021.

Klaus, Elisabeth and Ricarda Drüeke. "Öffentlichkeit und Privatheit: Frauenöffentlichkeiten und feministische Öffentlichkeiten." In Handbuch Frauen- und Geschlechterforschung, edited by Ruth Becker and Beate Kortendiek, 237-244. Wiesbaden: VS Verlag, 2008.

Köppert, Katrin. "Feministische Kunst und Überwachung. Eine un-/heilvolle Liaison?" Heinrich Böll Stiftung, April 1, 2019. https://www.gwi-boell.de/de/2019/04/01/feministische-kunst-undueberwachung-eine-un-heilvolle-liason <accessed on January 24, 2021>

Leap, William L. ed. Public Sex/Gay Space. New York: Columbia University Press, 1999.

Lingel, Jessica. "Dazzle camouflage as queer counter conduct." European Journal of Cultural Studies (February 2020): 1-18.

Lorenz, Renate. Queer Art: A Freak Theory. Bielefeld: Transcript, 2012.

Marx, Gary T. "Surveillance." In Encyclopedia of Privacy Vol. 2, edited by William G. Staples, 534-535.Westport, London: Greenwood, 2007.

Min, Susette. "Remains to Be Seen: Reading the Works of Dean Sameshima and Khanh." In Loss: The Politics of Mourning, edited by David L. Eng and David Kazanjian, 229-50. Berkeley: University of California Press, 2002.

--_. "The Mourning After: Art of Loss." In The Morning After: Art of Loss (Brochure for the Exhibition of the Same Name in The Los Angeles Municipal Art Gallery in Los Angeles 03/03/1999-04/18/1988), edited by Los Angeles Municipal Art Gallery, 4-18. Los Angeles, 1999.

Muñoz, José Esteban. Cruising Utopia: The Then and There of Queer Futurity. New York and London: New York University Press, 2009.

--_. "Ephemera as Evidence: Introductory Notes to Queer Acts." Women \& Performance: A Journal of Feminist Theory 8, no. 2 (1996): 5-16.

Neward, Tim. Camouflage. London: Thames \& Hudson, 2007.

Neward, Tim, Quentin Newark and J. F. Borsarello. Brassey's Book of Camouflage. London: Brassey's, 2007.

Pateman, Carole. "Feminist Critiques of the Public/Private Dichotomy." In Public and Private in Social Life, edited by Stanley I. Benn and Gerald F. Gaus, 281-303. New York: St. Martin's, 1983.

Phelan, Peggy. Unmarked: The Politics of Performance. New York; London: Routledge, 1993.

Ricco, John Paul. The Logic of the Lure. Chicago: University of Chicago Press, 2003.

Richardson, Lisa. “Zoning Board Rules That Bathhouse Is Sex Club: Regulation: Decision Mean Officials Will Seek to Close Wilmington Operation. Owner Denies Sex Was Allowed on the 
Premises and Blames Actions on Homophobia." Los Angeles Times, November 18, 1993. https:// www.latimes.com/archives/la-xpm-1993-11-18-me-58196-story.html <accessed on July 1, 2020>

Sameshima, Dean [thesecrethistorian]. "A very important Southern California institution for gay, bi, queer men has closed due...” [Instagram-Post, June 16, 2020], Instagram. https:// www.instagram.com/p/CBgRxfcIZzn/?utm_source=ig_web_copy_link <accessed on July 1, 2020>. Sanders, Joel ed. Stud. Architectures of Masculinity. New York: Princeton Architectural Press, 1996. Schade, Sigrid, and Silke Wenk. Studien zur visuellen Kultur: Einführung in ein transdisziplinäres Forschungsfeld. Bielefeld: Transcript, 2011.

Schaffer, Johanna. Ambivalenzen der Sichtbarkeit: Über die visuellen Strukturen der Anerkennung. Bielefeld: Transcript, 2008.

Schulz, Paul, and Christian Lütjens eds. Positive Pictures: A Gay History. Berlin: Bruno Gmünder Verlag GmbH, 2013.

Shell, Hannah Rose. Hide and Seek. Camouflage, Photography, and the Media of Reconnaissance. New York: Zone Books, 2012.

Stolberg, Sheryl. "Bathhouse Near School Appeals Closure Order." Los Angeles Times, July 7, 1988. https://www.latimes.com/archives/la-xpm-1988-07-07-me-8099-story.html <accessed on May 25, 2020>

Szcésniak, Magda. "Blending In and Standing Out-Camouflage and Masking as Queer Tactics of Negotiating Visibility.” View. Theories and Practices of Visual Culture 5, (2014): 1-28.

Tattelman, Ira. "The Meaning at the Wall: Tracing the Gay Bathhouse." In Queers in Space: Communities/Public Spaces/Sites of Resistance, edited by Gordon Brent Ingram, Anne-Marie Bouthillette, and Yolanda Retter, 391-406. Seattle, Wash.: Bay Press, 1997.

T., Anna. Opacity - Minority - Improvisation. An Exploration of the Closet Through Queer Slangs and Postcolonial Theory. Bielefeld: transcript, 2020.

Walkowiak, Jeffrey. "Resisting Documentation. Public Parks and Sex Clubs with Dean Sameshima.” Pablo Internacional Magazine, (2006): 8-13.

Weinberg, Jonathan. Speaking for Vice: Homosexuality in the Art of Charles Demuth, Marsden Hartley, and the First American Avant-Garde. London: Yale University Press, 1995.

Wilkinson, Jayne, "Art Documents: The Politics of Visibility in Contemporary Photography." InVisible Culture: An Electronic Journal for Visual Culture 22, (2015). http://ivc.lib.rochester.edu/artdocuments-the-politics-of-visibility-in-contemporary-photography/ <accessed on January 24, 2021>

\section{NOTES}

1. Dean Sameshima (b. 1971 in Torrance, California) lives and works in Berlin. In his* art he* explores the history of male* homosexuality, subcultures and the politics of desire through photography, painting, video, and installation. Sameshima received his* Bachelor's degree from the California Institute of Arts in Valencia, California, and an MFA from the Art Center College of Design in Pasadena, California. He* is represented by Gavlak Gallery in Los Angeles/Palm Beach. For more information, see the artist's website: http://www.deansameshima.com.

2. I start my analysis from the presentation of $I B D(W Y)$ which was part of the exhibition Art AIDS America (11/01/2016-04/02/2017) at the Alphawood Gallery in Chicago. I note that the series, 
which now consists of several editions, also included fewer and partly different photographs in previous publication contexts (exhibitions, artist books, etc.).

3. The fact that, to the best of my current knowledge, there are no comparable photographic (art) projects that depict L.A.'s baths for MSM from the inside during, or shortly after, the peak of the AIDS epidemic characterizes $I B D(W Y)$ as unique. The only two exceptions known to me are Frank Melleno's polaroids taken during the spring and summer of 1978 at the Fairoaks Hotel (a San Francisco bathhouse) and a photograph by Michael Buitron from 2008 that depicts a private room of the Klyt Bathhouse in Los Angeles in homage to Sameshima's $\operatorname{IBD}(W Y)$ (Ode to Dean Sameshima; Room 15, Klyt Bathhouse).

4. For a short introduction, see John Beynon, "Bathhouses and Sex Clubs," in Gay Histories and Cultures, ed. George E. Haggerty (New York: Taylor \& Francis Inc, 2000), 155-59; Allan Bérubé, "The History of Gay Bathhouses," in Policing Public Sex: Queer Politics and the Future of AIDS Activism, ed. Dangerous Bedfellows (Boston, MA: South End Pr, 1999), 187-220.

5. In the context of this article, I understand cruising as a deliberate, active, and usually mobile search for anonymous sex by homosexual men* in a social environment, which requires everyone involved to be able to decipher coded behavior or coded language. For the history of gay cruising and its political and cultural forces, see Alex Espinoza, CRUISING: An Intimate History of a Radical Pastime (North America: Unnamed Press, 2019).

6. In commercial LGBTIQ+ establishments (such as bars, nightclubs, baths or sex clubs), a darkroom can also be a cruising zone where anonymous sexual activities take place. The abbreviation LGBTIQ+ stands for lesbian, gay, trans, inter, queer and other sexual and/or gender identities that deviate from heteronormative ones. It should be noted that by choosing this acronym, I am not seeking to simplify things but rather to be open up to a plurality of sexualities and gender identities, thus hoping to contribute to the social and artistic recognition of the people who identify with and form these communities.

7. The "blank" is a basic concept of reception aesthetics introduced into literary theory by Wolfgang Iser, which refers to the punctual incompleteness of each picture. See Wolfgang Iser, Der Implizite Leser: Kommunikationsformen des Romans von Bunyan bis Beckett (München: Wilhelm Fink Verlag, 1972). On the function of blanks in art, see Wolfgang Kemp, ed, Der Betrachter ist im Bild: Kunstwissenschaft und Rezeptionsästhetik (Berlin: Dietrich Reimer Verlag, 1992).

8. For an introduction to the studies on visual culture, see Sigrid Schade and Silke Wenk, Studien zur visuellen Kultur: Einführung in ein transdisziplinäres Forschungsfeld (Bielefeld: Transcript, 2011).

9. The fact that there is no simple connection between visual representation and political power for minoritarian subject positions has been pointed out by Peggy Phelan, Unmarked: The Politics of Performance (New York; London: Routledge, 1993) and Johanna Schaffer, Ambivalenzen der Sichtbarkeit: Über die visuellen Strukturen der Anerkennung (Bielefeld: Transcript, 2008) as well as others.

10. On the politicization of the gaze in queer communities as both a form of harm from intolerant, hegemonic authority figures and as an identifying mode of recognition, solidarity, and desire, see Caroline Evans and Lorraine Gamman, "The gaze revisited, or reviewing queer viewing," in A Queer Romance: Lesbians, Gay Men and Popular Culture, ed. Paul Burston and Colin Richardson (New York: Routledge, 1995), 13-56.

11. See Gary T. Marx, "Surveillance," in Encyclopedia of Privacy, Vol. 2, ed. William G. Staples (Westport, London: Greenwood, 2007), 534-535.

12. Andrea Mubi Brighenti, "Artveillance: At the Crossroads of Art and Surveillance," in Surveillance \& Society 7, no. 2 (2010): 175-186. Zac Blas, Kat Köppert, Jessica Lingel, and Magda Szcześniak have confirmed this thesis by looking at different phenomena of art and visual culture through the interdisciplinary lens of surveillance studies and queer theory. Zach Blas, ed, In Practice: Opacities. Camera Obscura: Feminism, Culture, and Media Studies 31, ((2 92)), September 2016; Katrin Köppert, "Feministische Kunst und Überwachung. Eine un-/heilvolle Liaison?," 
Heinrich Böll Stiftung, April 1, 2019. https://www.gwi-boell.de/de/2019/04/01/feministischekunst-und-ueberwachung-eine-un-heilvolle-liason <accessed on January 24, 2021>; Jessica Lingel, "Dazzle Camouflage as Queer Counter Conduct," European Journal of Cultural Studies, (February 2020): 13; Magda Szcésniak, "Blending In and Standing Out - Camouflage and Masking as Queer Tactics of Negotiating Visibility," View. Theories and Practices of Visual Culture 5, (2014): 1-28. For a discussion on what (philosophical) potentials the merger of surveillance studies and queer theory hold, see in particular Nadine Dannenberg, "Queer Surveillance Studies. Überlegungen zu der Schnittstelle von Queer Theory und Surveillance Studies," GENDER 3, (2019): 26-40; Gary Kafer and Daniel Grinberg, "Editorial: Queer Surveillance," Surveillance \& Society 17, no. 5 (2019): 592-601.

13. Phelan, Unmarked, 6 .

14. Lee Edelman, Homographesis: Essays in Gay Literary and Cultural Theory (London and New York: Routledge, 1994); Rosemary Hennessy, Profit and Pleasure: Sexual Identities in Late Capitalism (New York and London: Routledge, 2000).

15. Phelan, Unmarked, 6.

16. On the politics of visibility as a highly contested topic within queer theory and activism see, among others, Edelman, Homographesis; Hennessy, Profit and Pleasure; Peggy Phelan, Unmarked; Johanna Schaffer, Ambivalenzen der Sichtbarkeit.

17. See Susette Min, "The Mourning After: Art of Loss," in The Morning After: Art of Loss (Brochure for the Exhibition of the Same Name in The Los Angeles Municipal Art Gallery in Los Angeles 03/03/1999-04/18/1999), ed. Los Angeles Municipal Art Gallery (Los Angeles, 1999), 4-18; Susette Min, "Remains to Be Seen: Reading the Works of Dean Sameshima and Khanh." In Loss: The Politics of Mourning, edited by David L. Eng and David Kazanjian, 229-250. Berkeley: University of California Press, 2002; Andy Campbell, Bound Together. Leather, Sex, Archives, and Contemporary Art (Manchester: Manchester University Press, 2020), 112.

18. See Rock Hushka, "It's an Image of Sex. It's Not about AIDS. The Legacy of the AIDS Crisis on American Art (It's Never Not about HIV)," GIA Reader 22, no. 3 (2011). https://www.giarts.org/ article/it\%E2\%80\%99s-image-sex-it\%E2\%80\%99s-not-about-aids <accessed on June 12, 2020>; Paul Schulz and Christian Lütjens, eds, Positive Pictures: A Gay History (Berlin: Bruno Gmünder Verlag $\mathrm{GmbH}, 2013), 193$; Rock Hushka: "Undetectable. The Presence of HIV in Contemporary American Art." In Art AIDS America, edited by Rock Hushka and Jonathan David Katz (Seattle; London: University of Washington Press, 2015), 139; Campbell, Bound Together, 112.

19. See Michael Buitron, "From Laud Humphries to Dean Sameshima: An Ode to the Continuum of Desire (Part 1)," in Leap Into the Void (Blog), 10/07/2008. https://imoralist.blogspot.com/2008/10/ from-laud-humphries-to-dean-sameshima.html <accessed on May 15, 2021>; Andy Campbell, "Dean Sameshima: Public Sex (Brochure for the Exhibition of the Same Name in the She Works Flexible gallery in Houston 05/05/2016-06/03/2016)," 2016, [no page].

20. See Jih-Fei Cheng, "Development is a Façade: Dean Sameshima's In Between Days (Without You) and the Queer Ecologies of Downtown Los Angeles," Lecture on March 11, 2017 in the context of the conference Viral Representation: On Aids and Art. A Conference (03/10/2017-03/11/2017) at Alphawood Gallery in Chicago. https://vimeo.com/210682462 <accessed on May 15, 2021>.

21. See Oliver Klaassen, "Fotografische Ambiguität \& getarnte Queerness: Der Versuch einer exemplarischen Verhältnisbestimmung," in Mehrdeutigkeit gestalten: Ambiguität und die Bildung demokratischer Haltungen in Kunst und Pädagogik, eds. Ansgar Schnurr, Sabine Dengel, Julia Hagenberg, and Linda Kelch (Bielefeld: Transcript, 2021), 253-271.

22. See Min, "The Mourning After," 4-18; Min, "Remains to Be Seen," 229-250.

23. Cheng, "Development is a Façade."

24. See Andy Campbell, "Dean Sameshima," [no page]; Campbell, Bound Together, 112; Hushka, "It's an Image of Sex"; Hushka, "Undetectable," 128-141; Klaassen, "Fotografische Ambiguität \& getarnte Queerness," 253-271. 
25. See Buitron, "From Laud Humphries to Dean Sameshima"; Campbell, "Dean Sameshima," [no page]; Campbell, Bound Together, 112.

26. Most of the research on $I B D(W Y)$ predominantly features incorrect information about the shooting locations. For example, Rock Hushka and Susette Min mistakenly refer to IBD(WY)'s recording locations as sex clubs (Hushka, "Undetectable," 236). Christian Lütjens and Paul Schulz speak of "orphaned darkroom flatbeds" (Schulz and Lütjens, Positive Pictures, 193).

27. Following poststructuralist and deconstructivist approaches, which emphasize the performative and transformative potential of the visual, my analysis of Sameshima's $\operatorname{IBD}(W Y)$ is based on a broadened approach to representation, which combines semiotics, discourse analysis, and gender studies. The critique of representations aims not only to make visible formative and often unquestioned image patterns but also to deconstruct and, if possible, change them. More details on the topic of the critique of representation can be found-among others-in Stuart Hall, ed, Representation: Cultural Representations and Signifying Practices (London: Sage Publications Ltd., 1997).

28. I developed this notation together with my colleagues Cathérine Ludwig-Ockenfels, Jana Tiborra, and Katharina Wolf for the international conference Renegotiating Minoritarian In_-_Visibilities (11/12-11/14/2019, Justus Liebig University Giessen, Germany) to mark the relationship between visibility and invisibility as a potential reciprocal relationship.

29. For an introduction to the queer tactic of camouflage in art and visual culture, see Jonathan D. Katz and David C. Ward, Hide/Seek: Difference and Desire in American Portraiture (Washington, D.C.: Smithsonian Institution, 2010; Szcésniak, "Blending In and Standing Out." For an introduction to the queer tactic of opacity in art and visual culture, see Blas, In Practice: Opacities. 30. What all of the following conceptualizations, with their focus on the illegible and unrecognizable, have in common is the success or failure of getting the (coded) message across: queer darkness (Jack Halberstam, The Queer Art of Failure (Durham: Duke University Press, 2011)), queer escape (José Esteban Muñoz, Cruising Utopia: The Then and There of Queer Futurity (New York and London: New York University Press, 2009)), queer opacity (Blas, ed. In Practice: Opacities), queer camouflage (Katz and Ward, Hide/Seek; Szcésniak, "Blending In and Standing Out," 1-28), poetic postmodernism (Jonathan D. Katz, "How AIDS Changed American Art," in Art AIDS America, ed. Rock Hushka and Jonathan David Katz (Seattle; London: University of Washington Press, 2015). 24-45), queer silence and passivity (Jonathan D. Katz, “John Cage's Queer Silence; or, how to Avoid Making Matters Worse," GLQ 5, no. 2 (1999): 231-252), abstract drag (Renate Lorenz, Queer Art: A Freak Theory (Bielefeld: transcript, 2012)), queer abstraction (David Getsy, "Then Queer Theses on Abstraction," in Queer Abstraction, ed. Jared Ledesma (Des Moines: Des Moines Art Center, 2019), 65-75).

31. Very much like what queer theory does, I see queer as a verb in the sense of queering normative knowledges, identities, and institutions. Queer theory is a theoretical approach that goes beyond queer studies to question the categories and assumptions on which current popular and academic understandings are based. Some unifying features of most queer theories are: resisting the categorization of people; challenging the idea of essential identities, questioning binaries; demonstrating how things are contextual, based on geography, history, culture, etc.; examining the power relations underlying certain understandings, categories, identities, etc. For an introduction to queer theory, see, among others, Annemarie Jagose, Queer Theory: An Introduction (New York: New York University Press, 1997); Donald E. Hall and Annamarie Jagose, eds, The Routledge Queer Studies Reader (London; New York: Routledge, 2012).

32. STEAM. A Quarterly Journal for Men, 3, no. 4 (Winter 1995/96). Sameshima's photograph of the Alondra Park tearoom can be found on page 418, the other two photographs of the Dockweiler State Beach tearoom are on page 443.

33. See Aaron Betsky, Queer Space: Architecture and Same Sex Desire (New York: William Morrow, 1997), 164. 
34. The atmosphere in 1350's popular small rooms was described by David Haldane in 1986 as follows, "Some of the doors stand open, revealing single black-lighted beds upon which naked patrons rest in various attitudes of repose. Most doors stay shut, hiding from view what takes place within the tiny rooms they protect." David Haldane, "Gay Bathhouse Under Pressure to Find Privacy for Sexual Acts," Los Angeles Times, April 27, 1986. https://www.latimes.com/ archives/la-xpm-1986-04-27-hl-23919-story.html <accessed on October 13, 2019>

35. Lisa Richardson, “Zoning Board Rules That Bathhouse Is Sex Club: Regulation: Decision Mean Officials Will Seek to Close Wilmington Operation. Owner Denies Sex Was Allowed on the Premises and Blames Actions on Homophobia," Los Angeles Times, November 18, 1993. https:// www.latimes.com/archives/la-xpm-1993-11-18-me-58196-story.html <accessed on July 1, 2020>

36. Sameshima, from an unpublished conversation with me recorded on September 9 in 2019 in his* Berlin studio.

37. Although, according to the artist, hundreds of photographs were taken in this context, he* selected only fifteen photographs for the series. Sameshima, unpublished conversation, 09/09/2019.

38. For a good introduction on the art history of the bed, see the catalog which was published on the occasion of the exhibition Sleepless - The Bed in History and Contemporary Art (30/01-06/7/2017) at the 21st Haus of the Belvedere in Vienna. Agnes Husslein-Arco and Mario Codognato, eds, Schlaflos - Das Bett in Geschichte und Gegenwartskunst / Sleepless - The Bed in History and Contemporary Art (Wien: Belvedere, 2015).

39. On the bed and its (photographic) reproduction as a sign of intimacy, see Thomas Jung and Stefan Müller-Dohm, "Kultur und Natur im Schlafraum," in Kulturinszenierungen, eds. Klaus Neumann-Braun and Stefan Müller-Dohm (Frankfurt am Main: Suhrkamp Verlag, 1995), 239-261.

40. See Agnes Husslein-Arco, "Vorwort / Foreword," in Schlaflos - Das Bett in Geschichte und Gegenwartskunst / Sleepless - The Bed in History and Contemporary Art, eds. Agnes Husslein-Arco and Mario Codognato (Wien: Belvedere, 2015), 8.

41. David Haldane, "Anti-AIDS Crusader Attacks Relocation of Gay Bathhouse," Los Angeles Times, July 17, 1986. https://www.latimes.com/archives/la-xpm-1986-07-17-cb-21512-story.html $<$ accessed on October 13, 2019>

42. Sheryl Stolberg, "Bathhouse Near School Appeals Closure Order," Los Angeles Times, July 7, 1988. https://www.latimes.com/archives/la-xpm-1988-07-07-me-8099-story.html <accessed on May 25, 2020>.

43. Glen Moering in Haldane, "Gay Bathhouse Under Pressure."

44. Erwin J. Haeberle, "Die Schließung der Schwulenbäder in San Francisco," in Sexualwissenschaft und Sexualpolitik. Spannungsverhältnisse in Europa, Amerika und Asien, eds. Rolf Gindorf and Erwin J. Haeberle (Berlin and New York: Walter de Gryter, 1992), 187-194.

45. Another example is the case of Bowers v. Hardwick. In 1986 Michael Hardwick was caught by a policeman* at home in bed with another man*, and this instance led to the landmark decision by the US Supreme Court to declare sexual intercourse between two adults of the same sex illegal. For more information see Ali Khan, "The Invasion of Sexual Privacy," San Diego Law Review 23, 1986: 957-977.

46. Michel Foucault positions sexuality as the central hinge between the two spheres of the private and the public spheres, stating that their genesis is constitutively interdependent. See Michel Foucault, Der Wille zum Wissen. Sexualität und Wahrheit I (Frankfurt/Main: Suhrkamp, 1977).

47. See Marx, "Surveillance," 534-535.

48. See Lauren Berlant and Michael Warner, "Sex in der Öffentlichkeit," in Outside. Die Politik queerer Räume, eds. Matthais Hesse, Marc Siegel, and Michaela Wünsch (Berlin: b_books 2005 [2000]), 77-104.

49. See Carole Pateman, "Feminist Critiques of the Public/Private Dichotomy," in Public and Private in Social Life, eds. Stanley I. Benn and Gerald F. Gaus (New York: St. Martin's, 1983), 
281-303; Karin Hausen, "Öffentlichkeit und Privatheit. Gesellschaftspolitische Konstruktionen und die Geschichte der Geschlechterbeziehungen," in Frauengeschichte - Geschlechtergeschichte, eds. Karin Hausen and Heide Wunder (Frankfurt/Main, New York: Campus, 1992), 81-88; Elisabeth Klaus and Ricarda Drüeke, "Öffentlichkeit und Privatheit: Frauenöffentlichkeiten und feministische Öffentlichkeiten," in Handbuch Frauen- und Geschlechterforschung, eds. Ruth Becker and Beate Kortendiek (Wiesbaden: VS Verlag, 2008), 237-244.

50. Tattelman, Ira, "The Meaning at the Wall: Tracing the Gay Bathhouse," in Queers in Space: Communities/Public Spaces/Sites of Resistance, eds. Gordon Brent Ingram, Anne-Marie Bouthillette, and Yolanda Retter, (Seattle, Wash: Bay Press, 1997), 400.

51. This fact has also been demonstrated by other photographic art projects: Ryszard Kisiel travelled through Poland in the 1970s and -80s and photographed the cruising spots (bars, bathhouses, and parks) of cities such as Warsaw, Krakow, and Łódź as well as small towns such as Ploch, Radom, and Slupsk. Kaucyila Brooke has an ongoing documentary project entitled The Boy Mechanic (since 1996), which, among other things, consists of photographs of current and former lesbian bar locations in San Diego, Los Angeles, San Francisco, and at the East Bay. During the winter of 2014-15, and fifty years after an essential gay resource was published, Bob Damron's Address Book (1965), Forster Rudolph visited and photographed 78 addresses of gay bars and social spaces in the United States indexed by Damron in his* guide.

52. Jeffrey Walkowiak, "Resisting Documentation: Public Parks and Sex Clubs with Dean Sameshima," Pablo Internacional Magazine, (2006): 12.

53. For example, Min incorrectly assumes that all the photographs from $\operatorname{IBD}(W Y)$ were taken in the same room. See Min, "Remains to Be Seen," 236.

54. The history of baths for MSM in the 1980s and -90s shows that-contrary to discriminatory, homophobic, and stereotypical accusations-the owners demonstrably tried to actively counteract the spread of HIV/AIDS through preventive measures. See for example Ralph Bolton, John Vincke, and Rudolf Mak, "Gay Baths Revisited: An Empirical Analysis," GLQ: A Journal of Lesbian and Gay Studies 1, no. 3 (1994): 255-73; and Diane Binson and William J. Woods, eds., Gay Bathhouses and Public Health Policy (New York: Routledge, 2003).

55. Tattelman, "The Meaning at the Wall," 394.

56. Prior to the discovery of HIV/AIDS in 1982 there were approximately 160 baths for MSM located in most major cities in the US, in 1994 there were only 61 baths left. Tattelman, "The Meaning at the Wall," 399.

57. Richardson, "Zoning Board Rules That Bathhouse Is Sex Club."

58. Richardson, "Zoning Board Rules That Bathhouse Is Sex Club."

59. Dean Sameshima [homosexuals_anonymous], "A very important Southern California institution for gay, bi, queer men has closed due..." [Instagram-Post, June 16, 2020], Instagram. https://www.instagram.com/p/CBgRxfcIZzn/?utm_source=ig_web_copy_link <accessed on July $1,2020>$.

60. Jonathan Weinberg, Speaking for Vice: Homosexuality in the Art of Charles Demuth, Marsden Hartley, and the First American Avant-Garde (London: Yale Univ Press, 1995), 19.

61. Tattelman, "The Meaning at the Wall," 403.

62. George Chauncey, New York: Gender Gay, Urban Culture - and the Making of the Gay Male World, 1890-1940 (New York: Basic Books, 1995), 398.

63. In particular, see the artwork by Patrick Angus, Julien Ceccaldi, Madison Donnelly, Elmgreen \& Dragset, John Burton Harter, Danny Jauregui, Rori Midhani, Oren Pinhassi, Prem Sahib, João Pedro Vale and Nuno Alexandre Ferreira, John Walter, and Michael Wyne.

64. For example, Leo Bersani describes them as "ruthlessly ranked, hierarchized, and competitive." Leo Bersani, “Is the Rectum a Grave?," October 43, (1987): 206.

65. Something Ira Tattelman also points out: "While the baths may have replayed power dynamics and mirrored the dominant masculine script of mainstream society, they also helped 
reconfigure and redefine that power. The erotics of gay sex use irony and simulation. The roles of top and bottom, even the divisions between heterosexuals and homosexuals were often mobile in the baths. These reversals began to subvert forms of domination. Acts of masculinity became eroticised so that they stopped being analogous with straight society and became something else." Tattelman, "The Meaning at the Wall," 405.

66. Hannah Rose Shell, Hide and Seek: Camouflage, Photography, and the Media of Reconnaissance (New York: Zone Books, 2012), 10.

67. Shell, Hide and Seek, 10.

68. Hardy Blechmann and Alex Newman, eds., DPM Disruptive Pattern Material. An Encyclopaedia of Camouflage: Nature, Military, Culture (London: DPM, 2004), 122, 124-150, 232, 248; Tim Newark, Camouflage (London: Thames \& Hudson, 2007), 53-73, 84-85; Tim Newark, Quentin Newark and J. F. Borsarello, Brassey's Book of Camouflage (London: Brassey's, 2007), 15-20.

69. Jayne Wilkinson, "Art Documents: The Politics of Visibility in Contemporary Photography," InVisible Culture: An Electronic Journal for Visual Culture 22, (2015). http://ivc.lib.rochester.edu/artdocuments-the-politics-of-visibility-in-contemporary-photography/ <accessed on January 24 , 2021>

70. Shell, Hide and Seek.

71. Campbell, "Dean Sameshima," [no page].

72. In particular, see the artworks by Michael Buitron, Tom Burr or Dino Dinco.

73. Katz, "How AIDS Changed American Art," 37. Poetic postmodernism as artistic strategy, hiding its real emotional intention by pretending not to express anything personal or private, would go against the premise of postmodernism, evoking the death of the author. Katz criticizes Roland Barthes' 1967 text The Death of the Author, which emphasizes the responsibility of every reader in the process of constructing meaning in the context of art and thus locates the meaning of an artwork in the viewer. Katz, "How AIDS Changed American Art," 35-36.

74. Schulz and Lütjens, Positive Pictures, 190; translated by O. K.

75. Schulz and Lütjens, Positive Pictures, 193; translated by O. K.

76. Schulz and Lütjens, Positive Pictures, 189; translated by O. K.

77. Hushka, "It's an Image of Sex."

78. Édouard Glissant, Philosophie de la Relation, trans. O. K. (Paris: Gallimard, 2009, 69); Édouard Glissant, Poétique de la Relation (Paris: Gallimard, 1990), 203-209.

79. Glissant, Poétique de la Relation, 125-134, 204.

80. In short, an attitude towards the world that Glissant associates with the dazzling process of creolization. Édouard Glissant, Kultur und Identität. Ansätze zu einer Poetik der Vielheit, trans. by B. Thill (Heidelberg: Wunderhorn, [1996] 2005), 7-22.

81. Nicholas de Villiers, Opacity and the Closet: Queer Tactics in Foucault, Barthes, and Warhol (Minneapolis: University of Minnesota Press, 2014), 22.

82. Nicholas de Villiers, "Afterthoughts on Queer Opacity," InVisible Culture: An Electronic Journal of Visual Culture 22, (2015). https://ivc.lib.rochester.edu/afterthoughts-on-queer-opacity/ <accessed on January 24, 2021>.

83. De Villiers, "Afterthoughts on Queer Opacity."

84. See, among others, Blas, In Practice; Köppert, "Feministische Kunst und Überwachung"; Anna

T., Opacity - Minority - Improvisation: An Exploration of the Closet Through Queer Slangs and Postcolonial Theory (Bielefeld: transcript, 2020).

85. Zac Blas interviewed by Alicia Eler, "The Faceless of Tomorrow Begins Today," Hyperallergic, June 24, 2013. https://hyperallergic.com/73888/the-facelessness-of-tomorrow-begins-today/ $<$ accessed on January 24, 2021>

86. Lingel, "Dazzle Camouflage," 13.

87. Lingel, "Dazzle Camouflage," 13. 
88. E.g. affiliations between different groups affected by AIDS, such as gay men*, other MSM, sex workers, friends, family, etc.

89. It was the mass media reporting, especially with its victimizing and stigmatizing images of emaciated dying men*, which repeatedly marked the bed as a place of illness, suffering, and death. For example, one campaign published in 1992 by the Benetton company, in collaboration with the photographer Oliviero Toscani, shows the dying David Kirby, infected with HIV, being photographed in bed surrounded by his* desperate relatives.

90. In chronological order: Dangerous Bedfellows, eds., Policing Public Sex: Queer Politics and the Future of AIDS Activism (Boston, MA: South End Pr, 1996); Joel Sanders, ed., Stud: Architectures of Masculinity (New York Princeton Architectural Press, 1996); Betsky, Queer Space; William L. Leap, ed, Public Sex/Gay Space (New York: Columbia University Press, 1999).

91. For example, members of the organization Gay and Lesbian HIV Prevention Activists (GALHPA) (formed in 1995) have used the mainstream press to defame baths for MSM and gay promiscuity. Beynon, "Bathhouses and Sex Clubs," 159.

92. The activist group SexPanic!, founded in New York in 1997, not only condemned the curtailment of sexual freedom for homosexuals, but also tried to undermine the problematic equation of public sex and unsafe sex.

93. Douglas Crimp, "How to Have Promiscuity in an Epidemic," October 43, (1987): 270.

94. Betsky describes the hardly visible and ephemeral character of cruising as follows: "The space of cruising is difficult to see [...]. Its most fundamental characteristic is its ephemerality: it is a space that appears for a moment, then is gone, only to reappear when the circumstances are right. This queer space appears through an act of transformation that turns separation into its opposite, which is connection." Betsky, Queer Space, 142.

95. Walkowiak, "Resisting Documentation," 12.

96. John Paul Ricco describes cruising as a form of negligence that is resistant to a goal and a finality. John Paul Ricco, The Logic of the Lure (Chicago: University of Chicago Press, 2003), 11.

97. José Esteban Muñoz, "Ephemera as Evidence: Introductory Notes to Queer Acts," Women \& Performance: A Journal of Feminist Theory 8, no. 2 (1996): 6.

\section{ABSTRACTS}

By staging an encounter between surveillance studies, art studies and queer theory, this article explores a queerness that disrupts surveillance, a queerness that invests and takes seriously refusals of certain forms of recognition and visibility. For In Between Days (Without You) (1998), Dean Sameshima photographed deserted private rooms of $1350 \mathrm{Club}$ and Hollywood Spa, two former bathhouses in Los Angeles for men* who have sex with men* (MSM), which were, in the 1990s, under increasing conditions of continual surveillance due to conservative political trends and sexual panic fueled by AIDS. By choosing not to show human figures on a visual level and by concealing the locations of the baths linguistically, the artist found a way to convey a resistance to surveillance and cultural critique by showcasing the strengths of commercial cruising venues for men*-what is considered here as counter-surveillance tactics. By operating at the level of managing and subverting rather than avoiding surveillance, the use of tactics such as camouflage and opacity foreground how to (re-)negotiate and queer the visual sphere in this photographic art project. 
INDEX

Keywords: private rooms, queer(ing), counter-surveillance, camouflage, opacity

\section{AUTHOR}

\section{OLIVER KLAASSEN}

Oliver Klaassen is a research assistant at the Institute for Art and Visual Culture at Carl Ossietzky University, Oldenburg and a Ph.D. candidate at the International Graduate Centre for the Study of Culture (GCSC) of Justus Liebig University, Giessen, Germany. In addition, they serve as a board member of the German Gender Studies Association as well as an editorial board member for On_Culture: The Open Journal for the Study of Culture. Current research interests include: queer(ing) art studies, art and club culture, history and theory of photography, aesthetic ambiguity of and in contemporary art, as well as queer(ing) museum studies and curatorial studies.

Carl Ossietzky University, Oldenburg 